\title{
Environmental sustainability of grey water footprints in Peshawar Basin: Current and future reduced flow scenarios for Kabul River
}

\author{
Tariq Khan ${ }^{1,2^{*}}$, Hizbullah Khan ${ }^{2}$ \\ (1. Department of Environmental Sciences, University of Haripur, 22640, Pakistan; \\ 2. Department of Environmental Sciences, University of Peshawar, 25000, Pakistan)
}

\begin{abstract}
Assessing water pollution at basin level is a challenging task. In this study, the environmental sustainability of grey water footprints $\left(W F_{\text {grey }}\right)$ of Peshawar Basin in Pakistan was analysed. The release of nitrogen $(\mathrm{N})$ and phosphorus $(\mathrm{P})$ from point and non-point sources during the period 1986 to 2015 were studied. Water pollution level (WPL) for normal and $10 \%-50 \%$ future reduced runoff in Kabul River as a result of construction of dams was considered. Methodologies described in Water Footprint Assessment Manual and Grey Water Footprint Accounting Guidelines were followed. Results showed that 30 -year annual average of $\mathrm{N}$ and $\mathrm{P}$ discharges were $24.5 \times 10^{3} \mathrm{t} / \mathrm{a}$ and $10.9 \times 10^{4} \mathrm{t} / \mathrm{a}$ respectively. The discharge of $\mathrm{N}$ and $\mathrm{P}$ from non-point sources contribute $97 \%$ and $99 \%$ respectively. N related $W F_{\text {grey }}$ was $50 \times 10^{8} \mathrm{~m}^{3} / \mathrm{a}$ and $50 \times 10^{9} \mathrm{~m}^{3} / \mathrm{a}$ for P. WPL of $\mathrm{N}$ was within the sustainable limit for all reduced runoff scenarios while P-related WPL for normal runoff exceeded sustainable limits and was worse in each reduced runoff scenario. This study confirms the deteriorated water quality of Kabul River and the findings may be helpful for future planning and water resource management of the basin.
\end{abstract}

Keywords: sustainability, grey water footprint, nitrogen, phosphorus, water pollution, Kabul River, Pakistan DOI: $10.25165 /$ j.ijabe.20191204.4804

Citation: Khan T, Khan H. Environmental sustainability of grey water footprints in Peshawar Basin: Current and future reduced flow scenarios for Kabul River. Int J Agric \& Biol Eng, 2019; 12(4): 162-168.

\section{Introduction}

Water Pollution is a worldwide environmental issues ${ }^{[1]}$. Fresh water resources have been severely affected by agricultural runoff, sewage and industrial effluents in many regions ${ }^{[2-8]}$. The release of $\mathrm{N}$ and $\mathrm{P}$ into surface water constitute an important component of nutrients cycle, however over discharge of these nutrients may lead to eutrophication ${ }^{[9]}$. Rivers play an important role to assimilate agriculture runoff, industrial and sewage effluent besides water supply and power generation ${ }^{[10]}$. A large amount of $\mathrm{N}$ and $\mathrm{P}$ fertilizers are added to soil, in which a very small portion is taken up by plants while the rest enter into water bodies through leaching and runoff ${ }^{[11]}$. The global annual anthropogenic $\mathrm{N}$ and $\mathrm{P}$ load from agriculture, domestic and industrial sources are 32.6 and 15 million $t / a$ respectively ${ }^{[11,12]}$. In developing countries the discharge of $\mathrm{N}$ and $\mathrm{P}$ will increase by a factor 2.5 to 3.5 respectively till $2050^{[9]}$.

Like other developing countries Pakistan is also facing severe water scarcity and pollution problem. Water quality of rivers and streams are deteriorated due to direct discharge of untreated effluents into rivers ${ }^{[13]}$. It has been reported that pollution level in River Ravi has been increased 4-6 times from 1960 due to low flow in river after 'Indus Water Treaty'. River Ravi receives $21 \mathrm{~m}^{3} / \mathrm{s}$ of untreated effluents and became the most polluted river

Received date: $2018-11-28 \quad$ Accepted date: $2019-05-06$

Biographies: Hizbullah Khan, PhD, Professor, research interest: heterogeneous catalysis, integrated pest management, air and water pollution control: Email: hizbullah@uop.edu.pk.

*Corresponding author: Tariq Khan, Master, Lecturer, research interest: water footprint assessment, water pollution and sustainability. Room 104, Department of Environmental Sciences, Ibn-Hayatham Block, The University of Haripur, Haripur 22640, Khyber Pakhtunkhwa, Pakistan, Tel: +923129800675, Email: tariqkhan@uoh.edu.pk. in Pakistan ${ }^{[14]}$. Water quality of Kabul River has also been deteriorated due to lack of wastewater treatment facility. It receives about $1 \mathrm{~m}^{3} / \mathrm{sec}$ of industrial effluents directly without prior treatment ${ }^{[15-19]}$. Pakistan and Afghanistan both share water resources of Kabul River and any reduction in flow will have drastic impact on water quality of river. The Government of Afghanistan has developed a comprehensive future plan for power generation and irrigation on Kabul River ${ }^{[20,21]}$ (See appendix). These hydropower projects will result a significant reduction in volume of water to Peshawar Basin that will adversely affect capacity of Kabul River to assimilate pollutants loads ${ }^{[22]}$.

Earlier studies on Kabul River mainly focused on physico-chemical characteristics of water quality (summarized in Table 1). Some studies analysed heavy metals concentrations in water while others have determined the impacts of water pollution on fish and wheat irrigated with river water ${ }^{[23-46]}$. However, reports on the capacity of Kabul River to assimilate pollutants load and downstream impacts of future reduced flow on water quality as a result of construction of dams in Afghanistan have not been discovered.

The objectives of this study were (1) To analyse the environmental sustainability of $W F_{\text {grey }}$ and WPL in relation to N and $\mathrm{P}$ release from artificial fertilizers, animal manure, households and industrial sources during a period of 1986 to 2015 and (2) To determine the likely impacts of future reduced runoff from an increased use of water in Afghanistan. The concept of water footprints has been widely used in assessing environmental sustainability of blue water footprint of industrial parks, urban area and river basins ${ }^{[47-51]}$. The novelty of this study is that for the first time WPL was assessed for future reduced flow as a result of upstream use of water besides analysing environmental sustainability of $W F_{\text {grey }}$ at the basin level. 
Table 1 Water pollution studies on Kabul River in Peshawar Basin in Pakistan

\begin{tabular}{|c|c|c|c|c|c|c|c|c|c|c|}
\hline Year & Temp $/{ }^{\circ} \mathrm{C}$ & $\mathrm{pH}$ & $\begin{array}{l}\text { Cond } \\
/ \mu \mathrm{s}^{\cdot} \mathrm{cm}^{-1}\end{array}$ & $\begin{array}{l}\text { Alkalinity } \\
/ \mathrm{mg} \cdot \mathrm{L}^{-1}\end{array}$ & $\begin{array}{c}\mathrm{SO}_{4}{ }^{2-} \\
/ \mathrm{mg} \cdot \mathrm{L}^{-1}\end{array}$ & $\underset{/ \mathrm{mg} \cdot \mathrm{L}^{-1}}{\mathrm{DO}}$ & $\begin{array}{c}\text { BOD } \\
/ \mathrm{mg} \cdot \mathrm{L}^{-1}\end{array}$ & $\begin{array}{l}\mathrm{COD} \\
/ \mathrm{mg} \cdot \mathrm{L}^{-1}\end{array}$ & $\begin{array}{c}\mathrm{NO}_{3}^{-} \\
/ \mathrm{mg} \cdot \mathrm{L}^{-1}\end{array}$ & $\begin{array}{l}\mathrm{PO}_{4}{ }^{3-} \\
/ \mathrm{mg} \cdot \mathrm{L}^{-1}\end{array}$ \\
\hline $1982-83$ & 8.75 & 8.4 & & 284 & & 3.79 & 0.44 & 20.81 & & \\
\hline 1990 & 19.2 & 8.07 & 316 & & & & & & & \\
\hline 1994 & 22.22 & 7.58 & 362.98 & 117.68 & 44.32 & 6.43 & 3.1 & 81.75 & 4.91 & 0.52 \\
\hline 1997 & 25 & 7.65 & 265 & 92 & 31 & 6.3 & 2.6 & 78 & 1.26 & 0.3 \\
\hline 1999 & 15.5 & 8 & 290 & 154.54 & 115.02 & 9.48 & 3.32 & 47.57 & 0.51 & \\
\hline 2008 & & & & 159.23 & 140.61 & & 4.27 & 122.26 & 1.64 & 0.17 \\
\hline 2009 & & 7.6 & 467.56 & & 66.06 & 6.12 & & & 3.2 & \\
\hline 2010 & 23.33 & 7.55 & 206.4 & 123.86 & 163.99 & & 3.77 & & 1.28 & 0.11 \\
\hline 2011 & & & & & & 7.86 & & & & \\
\hline 2013 & & 7.6 & & & & 5.6 & & 116 & 10.3 & \\
\hline 2014 & 30.12 & 8.22 & & 232 & & & & & 0.32 & \\
\hline 2017 & & 8.08 & 335.66 & 148.66 & 14.4 & 7.2 & & & 0.75 & \\
\hline
\end{tabular}

\section{Study area}

Peshawar Basin is a sub-basin of Indus River Basin. It extended from $71^{\circ} 15^{\prime}$ to $72^{\circ} 45^{\prime}$ East longitude and from $33^{\circ} 45^{\prime}$ to $34^{\circ} 30^{\prime}$ North latitude in the province of Khyber Pakhtunkhwa, Pakistan (Figure 1) ${ }^{[23]}$. The basin covers an area of $5623 \mathrm{~km}^{2}$ with a population of 9.78 million $^{[52]}$. The last 30 years of land use show that Peshawar Basin consist of $60 \%$ agricultural land,
$27 \%$ pasture, $10 \%$ buildup, $1 \%$ water bodies and $1 \%$ barren land. Kabul River is the main river flowing through Peshawar Basin that originates from Unai Pass of Hindukush Mountains in Afghanistan. It runs approximately $700 \mathrm{~km}$ distance from Unai pass up to Indus River. The river flows about $560 \mathrm{~km}$ in Afghanistan and $140 \mathrm{~km}$ in Pakistan. In Afghanistan, it contributes about $26 \%$ of surface water flow ${ }^{[53]}$.

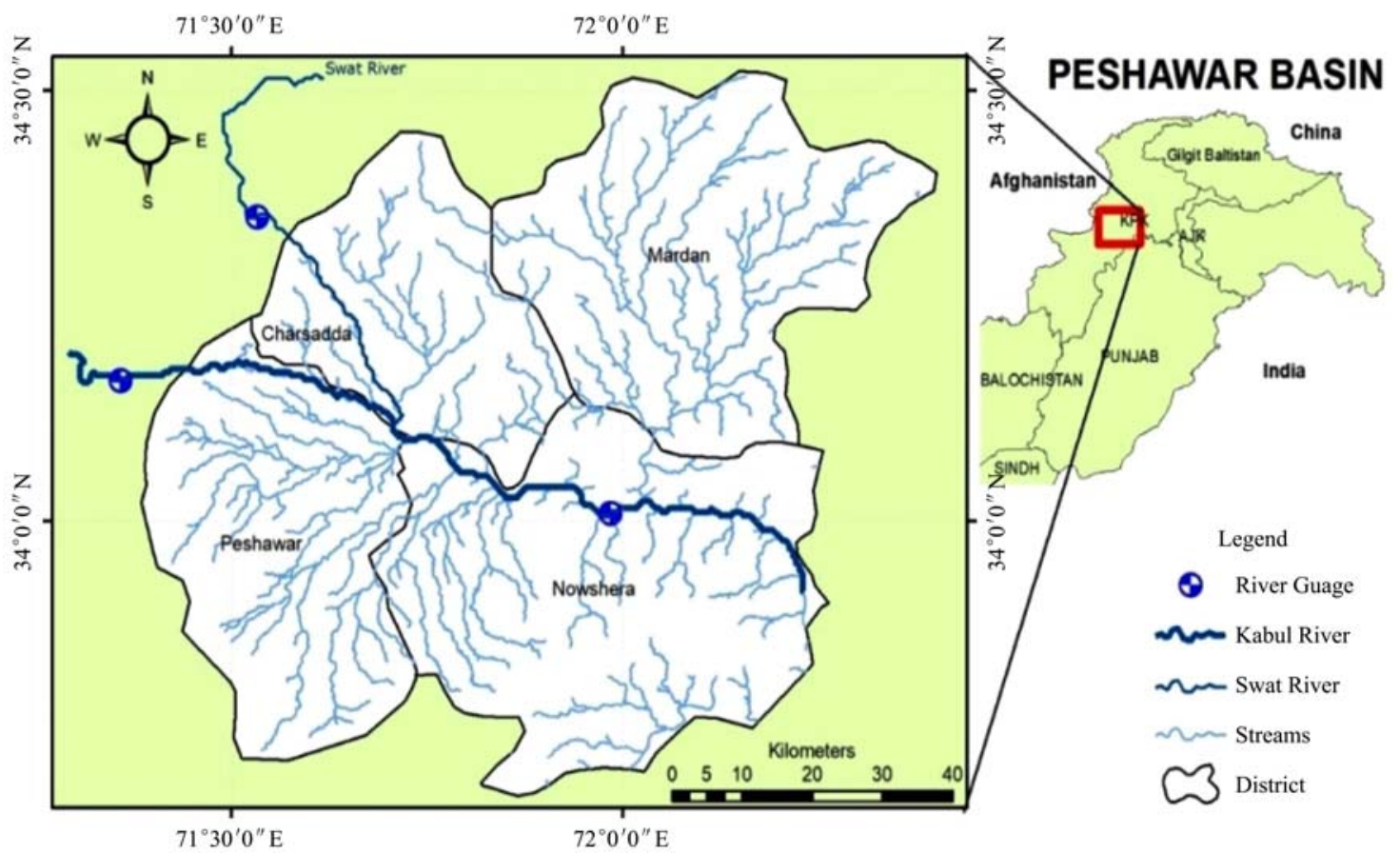

Figure 1 Kabul River passing through Peshawar Basin in Pakistan

\section{Materials and methods}

\subsection{Data description}

Artificial fertilizers data for the period of 1986 to 2015 was obtained from Pakistan's National Fertilizer Development Centre (NFDC) annual reports ${ }^{[54]}$. NFDC annually reports $\mathrm{N}$ and $\mathrm{P}$ nutrients in the form of urea, calcium ammonium nitrate (CAN), diammonium phosphate (DAP), single and triple superphosphate (SSP) and sulphate of potash (SOP) in the country. The N and P loads from livestock manure were calculated by multiplying livestock population by animal-specific excretion rates ${ }^{[55]}$. Livestock censuses data of 1986, 1996, and 2006 were converted to annual figures by interpolation while 2007 to 2015 population data was obtained from local livestock department. The slaughtered weights of animals in Pakistan for the years 1980, 1990 and 2000 are shown in Table $2^{[56,57]}$ and animal excretion rates were taken from Sheldrick et al. ${ }^{[58]}$ Ammonia volatization rates for cattle and poultry (36\%), and for buffaloes, sheep and goat (28\%) were taken from Bouwman et al. ${ }^{[59]}$ Human population censuses of 1981, 1998 and 2017 were converted into annual population by interpolation $^{[52]}$. The $\mathrm{N}$ and $\mathrm{P}$ loads from households and industrial sources were calculated from daily protein intake per capita following Van Drecht et al..$^{[9,11,12]}$ The daily protein intake for Pakistan during the period 1986 to 2015 was taken from 


\section{FAOSTAT $^{[60]}$.}

Table 2 Slaughtered weight and $\mathrm{N}$ and $P$ contents in various livestock categories

\begin{tabular}{|c|c|c|c|c|c|c|}
\hline \multirow{2}{*}{$\begin{array}{l}\text { Livestock } \\
\text { type }\end{array}$} & \multirow{2}{*}{$\begin{array}{c}\text { Slaughtered } \\
\text { weight } / \mathrm{kg}\end{array}$} & \multicolumn{2}{|c|}{$\begin{array}{c}\text { Nutrient/kg } \\
\text { (per slaughtered } \\
\text { weight per year) }\end{array}$} & \multicolumn{3}{|c|}{$\begin{array}{l}\text { Slaughtered weight in } \\
\text { Pakistan } / \mathrm{kg}\end{array}$} \\
\hline & & Nitrogen & Phosphorus & 1980 & 1990 & 2000 \\
\hline Cattle & 250 & 50 & 10 & 126.9 & 164 & 190.9 \\
\hline Buffaloes & 250 & 50 & 10 & 88.5 & 117.1 & 133.1 \\
\hline Horse & 250 & 45 & 8 & & & \\
\hline Asses & & 45 & 8 & & & \\
\hline Mules & & 45 & 8 & & & \\
\hline Sheep & 15 & 10 & 2 & 10.7 & 17.4 & 17 \\
\hline Goats & 12 & 10 & 2 & 9.6 & 15.5 & 17 \\
\hline Camels & 456 & 50 & 10 & 456 & & \\
\hline Poultry & 2 & 0.6 & 0.19 & 0.7 & 1 & 1.1 \\
\hline
\end{tabular}

The intake protein contains $16 \%$ of $\mathrm{N}$, about $97 \%$ of this intake is excreted while $3 \%$ is lost via hair, blood, skin etc. ${ }^{[9,61-64]}$ Since, Peshawar basin has no wastewater treatment plant to remove the $\mathrm{N}^{[65]}$, population connected to public sewerage system and removal of $\mathrm{N}$ and $\mathrm{P}$ through wastewater treatment was presented accordingly. Furthermore, the $\mathrm{N}$ load that enter the surface water is only $10 \%$ of $97 \%$. The $\mathrm{P}$ load from point sources were taken from $\mathrm{N}$ intake based on N: P ratio of 10:1. The industrial P load were taken as $15 \%$ of the urban household $\mathrm{P}$ loads ${ }^{[10,12]}$. Runoff data $\left(\mathrm{m}^{3} / \mathrm{a}\right)$ of Kabul River were obtained from Water and Power Development Authority ${ }^{[66]}$. In the absence of standard setup for surface water in Pakistan regarding maximum concentration $\left(C_{\max }\right)$ and natural concentration $\left(C_{n a t}\right)$ for both $\mathrm{N}$ and $\mathrm{P}$, the $C_{\max }$ of $2.9 \mathrm{mg} / \mathrm{L}$ and $C_{\text {nat }}$ of $0.4 \mathrm{mg} / \mathrm{L}$ for $\mathrm{N}$ and $C_{\max }$ of $0.02 \mathrm{mg} / \mathrm{L}$ and $C_{n a t}$ of $0.01 \mathrm{mg} / \mathrm{L}$ for P were taken from Mekonnen and Hoekstra ${ }^{[11,12]}$.

\subsection{Grey water footprint}

$W F_{\text {grey }}$ was calculated using Global Water Footprint Assessment Standard and Grey Water Footprint Accounting
Guidelines ${ }^{[67,68]}$. $\quad W F_{\text {grey }}\left(\mathrm{m}^{3}\right)$ was computed by dividing $\mathrm{N}$ and $\mathrm{P}$ loads $(\mathrm{t} / \mathrm{a})$ to the difference between the maximum acceptable concentration $\mathrm{C}_{\max }$ and the natural background concentration $C_{\text {nat }}$ of $\mathrm{N}$ and $\mathrm{P}^{[11,12,67,68]}$

$$
W F_{\text {grey }}=\frac{L}{\left(C_{\max }-C_{\text {nat }}\right)}
$$

where, $L$ is pollution load, $\mathrm{t} / \mathrm{a} ; L=\alpha \times$ application of $\mathrm{N}$ and $\mathrm{P}, \mathrm{t} / \mathrm{a} ; \alpha$ is leaching-runoff fraction; $C_{\max }$ is maximum allowable concentration, $\mathrm{t} / \mathrm{m}^{3} ; C_{\text {nat }}$ is natural background concentration, $\mathrm{t} / \mathrm{m}^{3}$.

\subsection{Water pollution level}

WPL was used for environmental sustainability analysis of $W F_{\text {grey }}$. WPL is the ratio of total $W F_{\text {grey }}$ in a basin to the actual runoff $\left(R_{a c t}\right)$ of river. A $100 \%$ value of $W P L$ indicate that waste assimilation capacity has been completely consumed and $W F_{\text {grey }}$ is unsustainable ${ }^{[67]}$.

$$
W P L=\frac{\sum W F_{\text {grey }}}{R_{\text {act }}} \times 100 \%
$$

where, $R_{a c t}$ is actual runoff, $\mathrm{m}^{3} / \mathrm{a}$.

\subsection{Reduced runoff scenarios}

The 30 years annual average (1986-2015) of $W F_{\text {grey }}$ and runoff of Kabul River were taken as reference value. The reference runoff is reduced by $10 \%, 20 \%, 30 \%, 40 \%$ and $50 \%$ to analyse the effect of flow on WPL for each reduced runoff $\left(R_{\text {reduced }}\right)$ scenario keeping the reference $W F_{\text {grey }}$ constant.

\section{Results}

\subsection{Application of $\mathbf{N}$ and $\mathbf{P}$ fertilizers}

The application of $\mathrm{N}$ and $\mathrm{P}$ fertilizers in Peshawar Basin from 1986-2015 are given in Figure 2. The data revealed that community has been using chemical fertilizers in huge amounts for intensive agricultural activities across the basin. Every passing year witness an apparent increment in application of $\mathrm{N}$ and $\mathrm{P}$ nutrients. The application of $\mathrm{N} \& \mathrm{P}$ fertilizers show that the water pollution level of $\mathrm{N}$ and $\mathrm{P}$ in river water is substantially attributed to the use of artificial fertilizers in Peshawar Basin.

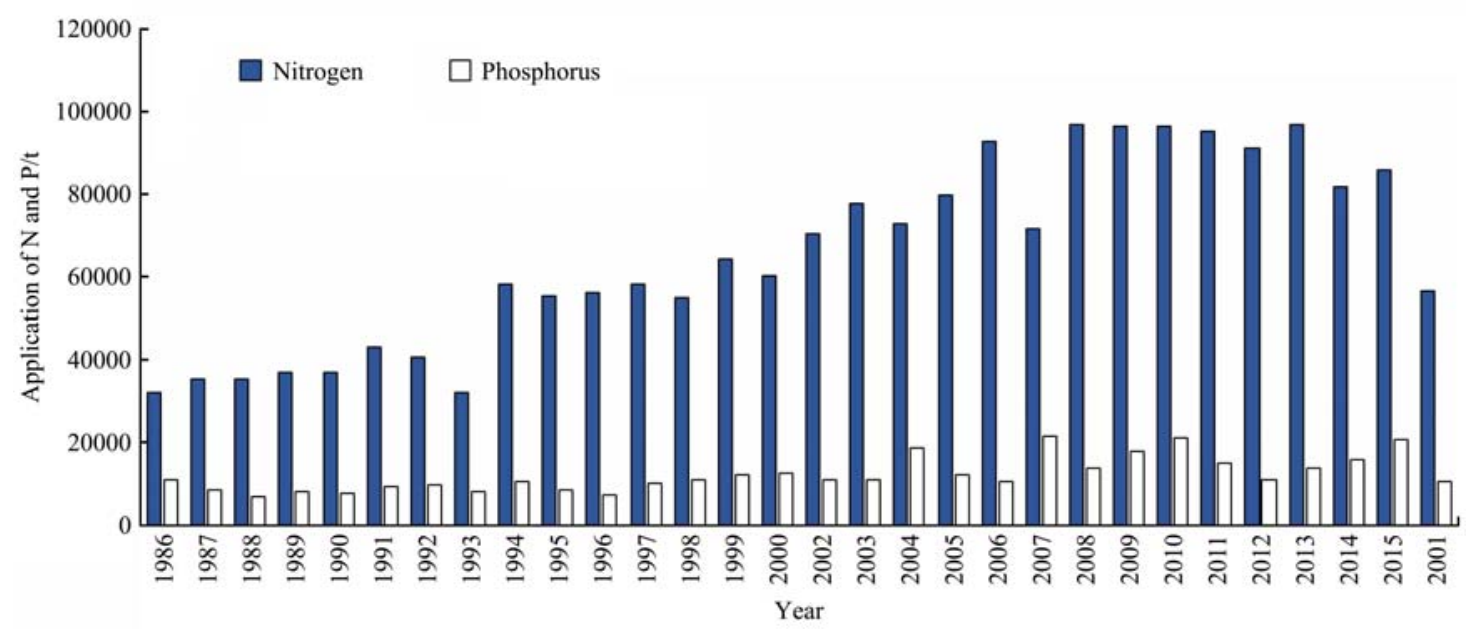

Figure 2 Application of $\mathrm{N}$ and $\mathrm{P}$ in Peshawar Basin from 1986-2015 (t/a)

\section{2 $\mathrm{N}$ and $\mathrm{P}$ loads from livestock manure}

$\mathrm{N}$ and $\mathrm{P}$ loads from livestock manure were measured by multiplying livestock population by manure production. During 30 -years period, average $\mathrm{N}$ and $\mathrm{P}$ loads from livestock manures in Peshawar Basin have been highly depended on the animal species. For instance, cattle manure contributed $50 \%$ to the $\mathrm{N}$ input of the basin, buffaloes $19 \%$, goat $16 \%$, equine $8 \%$, sheep $4 \%$ and camels $1 \%$. For $\mathrm{P}$ load, cattle manures contributed $37 \%$, sheep $28 \%$, buffaloes $14 \%$, goat $12 \%$, equine $5 \%$ and camels $1 \%$ (Figure 3 ). Changes in the $\mathrm{N}$ and $\mathrm{P}$ inputs could be attributed to the innate concentrations of these nutrients in manures as well as excretion rate per livestock.

\section{3 $\quad W F_{\text {grey }}$ of $\mathbf{N}$ and $\mathrm{P}$}

Average of 30-years N-related $W F_{\text {grey }}$ in Peshawar Basin showed that artificial fertilizer contributed $61 \%$, livestock manure $36 \%$, household sources $2 \%$ and industries $1 \%$. For P-related 
$W F_{\text {grey }}$, the contribution from artificial fertilizer, livestock manure and household sources were $50 \%, 49 \%$ and $1 \%$, respectively. The contribution from industrial sources was found as negligible (Figure 4).

Both N and P-related $W F_{\text {grey }}$ in Peshawar Basin were steadily increased over the period of 1986-2015. P-related $W F_{\text {grey }}$ exhibited higher values than N-related $W F_{\text {grey. }}$. During 1986, the $\mathrm{N}$-related $W F_{\text {grey }}$ was less than $30 \times 10^{8} \mathrm{~m}^{3} / \mathrm{a}$ whereas P-related $W F_{\text {grey }}$ was slightly above $40 \times 10^{8} \mathrm{~m}^{3} / \mathrm{a}$. However, after 30 years period the average $\mathrm{N}$-related $W F_{\text {grey }}$ exceeded the amount of $50 \times 10^{8} \mathrm{~m}^{3} / \mathrm{a}$ and P-related $W F_{\text {grey }}$ over the study period reached a level of $50 \times 10^{9} \mathrm{~m}^{3} / \mathrm{a}$ (Figure 5 ).

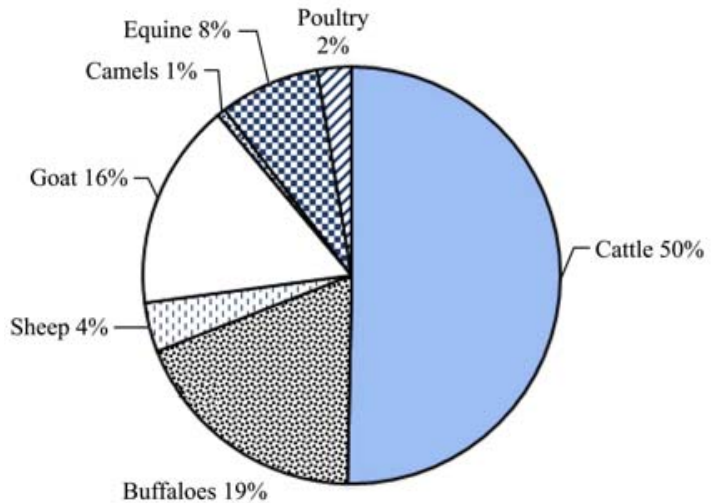

a. Nitrogen (\%) contributed by livestock manures

\subsection{WPL of $\mathbf{N}$ and $\mathrm{P}$}

Environmental sustainability of grey water footprint was analyzed using WPL. WPL for N and P were substantially enhanced during the period of 1986-2015. In the last 15 years, the increase in the water pollution was higher and fluctuated during the subsequent years. The consistent higher values of WPL in the last decade could be associated with the excessive human activities in the form of intensive agriculture, raising of livestock, industrialization and urbanization. The N-related WPL was within the sustainability limit of $100 \%$ for each passing year during the study period, whereas P-related WPL has exceeded the sustainability limit (Figure 6).

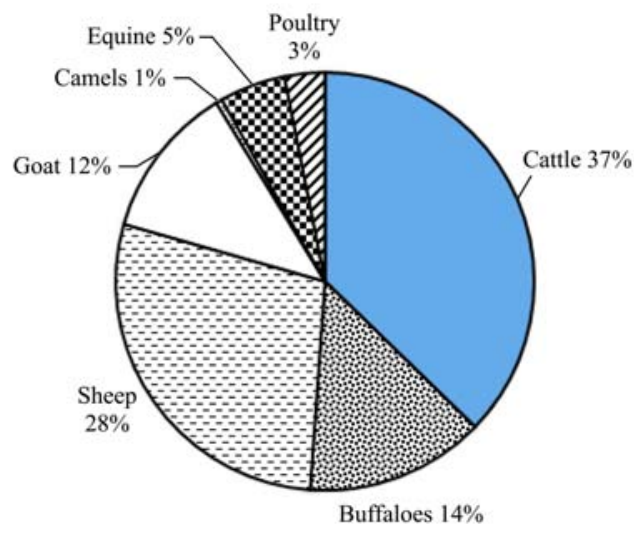

b. Phosphorus (\%) contributed by livestock maures

Figure 3 Input of $\mathrm{N}$ and $\mathrm{P}$ by different livestock in Peshawar Basin (average of 30 years)

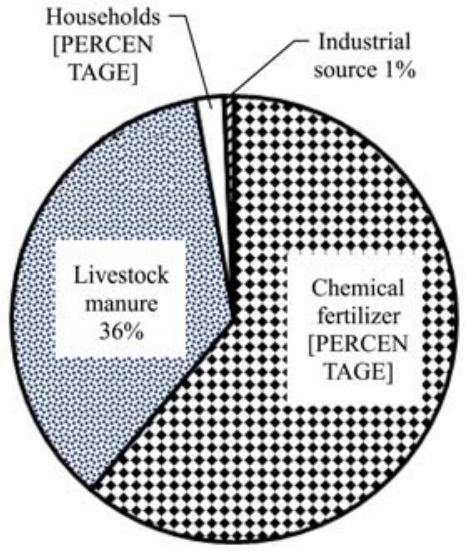

a. Nitrogen

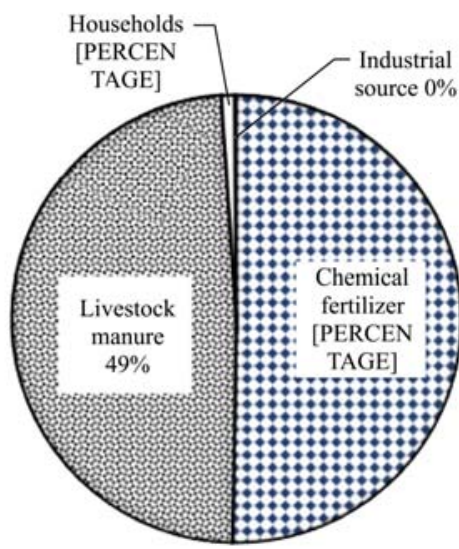

b. Phosphorus

Figure 4 Source to $W F_{\text {grey }}(\%)$ in Peshawar Basin (30 years average)

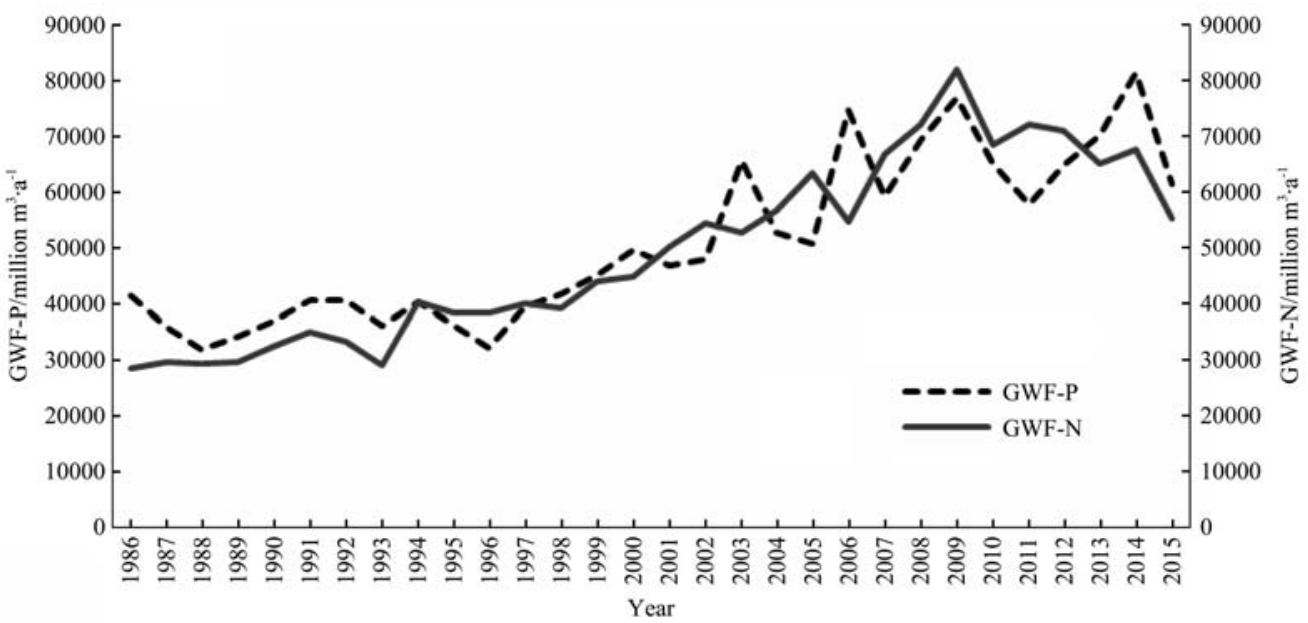

Figure $5 \mathrm{~N}$ and P-related $\mathrm{WF}_{\text {grey }}$ in Peshawar Basin during 1986-2015 


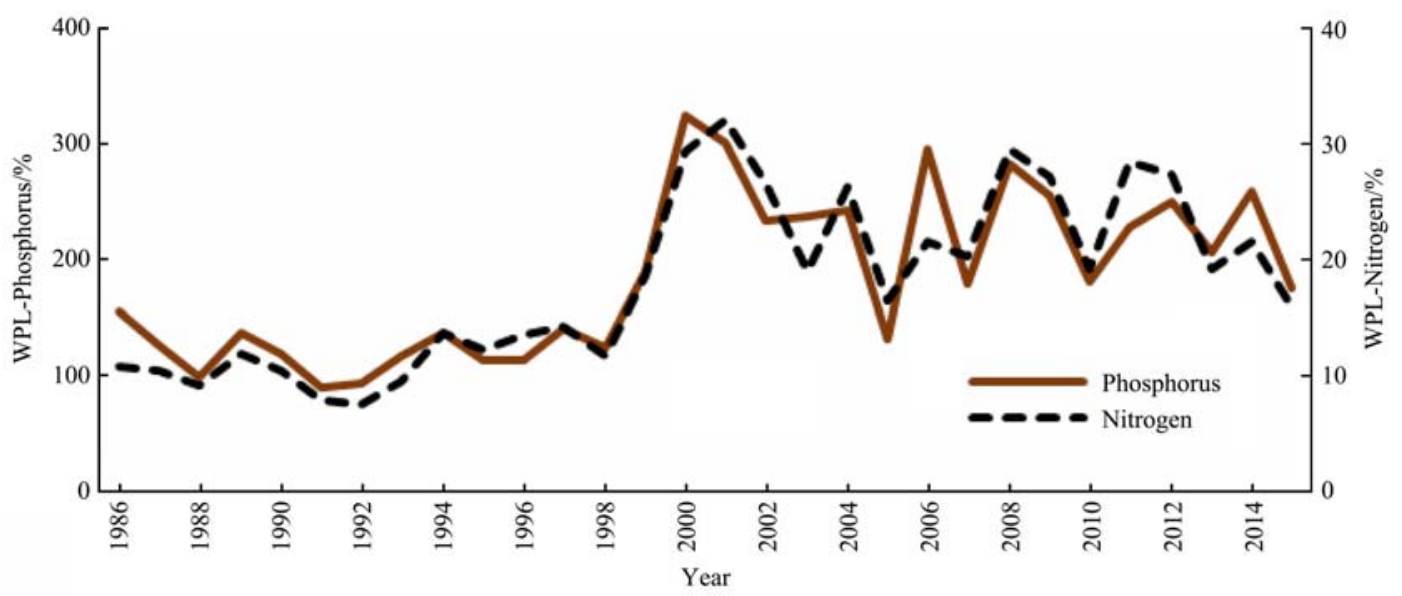

Figure 6 WPL in Kabul River in Peshawar Basin during 1986-2015

\subsection{WPL for reduced runoff scenarios}

The results of the $\mathrm{N}$ and P related WPL for the future reduced runoff scenarios of $10 \%, 20 \%, 30 \%, 40 \%$ and $50 \%$ are given in Figure 7. N-related WPL for the five simulated runoff scenarios were $19 \%, 21 \%, 24 \%, 28 \%$ and $34 \%$, respectively. All these values remained within the sustainability limit of $100 \%$. $P$ associated WPL exceeded the sustainability limit for each scenario. The WPL-P values were calculated in the following pattern $194 \%$, $218 \%, 249 \%, 291 \%$ and $349 \%$ respectively (Figure 7 ). Since P has exceeded the sustainability limits, decrease in the quantity of water or increase in the magnitude of $\mathrm{P}$ release may further exacerbate the quality of water in Kabul River. This situation could be harmful to ecosystem in terms of water quantity and quality after mixing of drainage water, untreated industrial and municipal wastewater with river water.

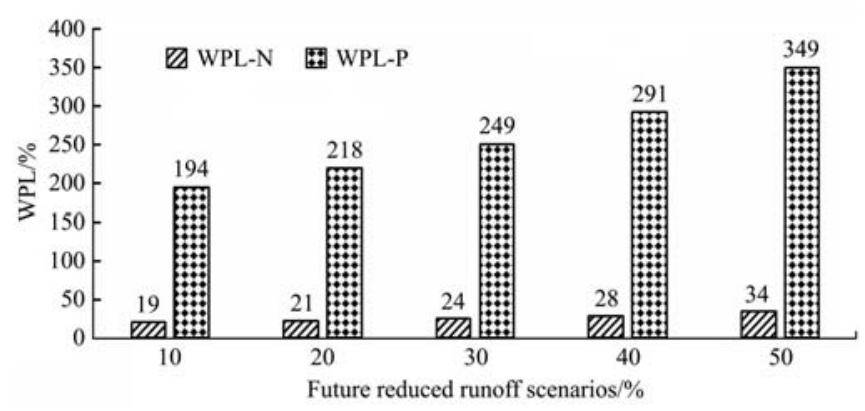

Figure $7 \mathrm{~N}$ and $\mathrm{P}$ related WPL for five different reduced-runoff scenarios in Peshawar Basin

\section{Discussion}

$W F_{\text {grey }}$ determines the sustainability of water resources. This study investigated $W F_{\text {grey }}$ for $\mathrm{N}$ and $\mathrm{P}$ load originated from different sources in Peshawar Basin during 1986 to 2015. Both N and P-related $W F_{\text {grey }}$ were steadily increased during the investigation period. The level of $W F_{\text {grey }}$ has been associated with factors like artificial fertilizers, livestock manures, household and industrial sources. $W F_{\text {grey }}$ of $\mathrm{N}$ and $\mathrm{P}$ ascertained that Peshawar basin has adversely affected the river water quality.

Unfortunately, there is no previous research concerning $W F_{\text {grey }}$ in Peshawar Basin for comparison. However, according to Mekonnen and Hoekstra ${ }^{[11]}$, N-related $W F_{\text {grey }}$ of Pakistan was 288 billion $\mathrm{m}^{3} / \mathrm{a}$ in 2002-2010, where 262 billion $\mathrm{m}^{3} / \mathrm{a}$ were from agriculture, 23 billion $\mathrm{m}^{3} / \mathrm{a}$ from households and 3 billion $\mathrm{m}^{3} / \mathrm{a}$ from industries. The Indus river basin has N-related $W F_{\text {grey }}$ of 440 billion $\mathrm{m}^{3} / \mathrm{a}$, as agriculture being the main contributor $(59 \%)$ and households as the second $(38 \%)^{[11]}$.
Nafees et $\mathrm{al}^{[69]}$ reported that $68 \%$ of wetlands in Peshawar Basin has been converted to agricultural fields due to low flow in Kabul River. This study showed that high P-related pollution in river over last 30 years lead to eutrophication of wetlands ${ }^{[70]}$ in the basin, and the local community convert these dry lands to agriculture fields that further increases pollution by escalating application of fertilizers. In the absence of any previous published work, this study confirms that environmental pollution has degraded the quality of water in Kabul River. This would render it unsuitable for agriculture or domestic water supply ${ }^{[71]}$.

The reduced runoff scenarios exhibited higher level of $\mathrm{N}$ - and P-related WPL and further reduction in volume of river water would certainly aggravate water quality. The proposed hydro projects in Afghanistan would result in reduced water flow to Peshawar Basin. This would adversely affect downstream ecosystems and communities dependent on $\mathrm{it}^{[20,21]}$. Monitoring pollution in Kabul River is an effort for a good water management in Pakistan. Based on the literature review, water in the Kabul River was found to be unsuitable for drinking but fit for the irrigation purpose. The reduced flow in Kabul River would severely affect Peshawar Basin's current and future water usages for crops and may lead to economic deterioration and health issues.

Since Kabul River is a shared resource of Pakistan and Afghanistan, both countries have the right to use it for their economic up-lift. Factors like climate change, increasing demand for water and concerns for environment would lead to complex disputes between two countries. The issue can be harmoniously resolved through an institutionalized agreement on sharing the Kabul river water equitably between the two riparian states. In Kabul river water treaty, optimal quality and quantity of water must be considered. Governments of both countries should take measures for the protection and conservation of water for sustainable economic and ecological activities such as fisheries, eco-tourism, recreation and watershed management. The deteriorating and depleting water resources of Kabul river system also suggest that the water resources of Kabul River should be safeguarded to avoid future conflicts.

\section{Conclusions}

It is concluded that both $\mathrm{N}$ and P-related $\mathrm{WF}_{\text {grey }}$ in Peshawar Basin were steadily increased during the last 30 years. In all reduced runoff scenarios the WPL-N value was within sustainability limits whereas WPL-P value has exceeded the sustainability limit. The deteriorating and depleting water 
resources of Kabul River suggested that the river must be safeguarded to avoid water quality and quantity issues. This study may serve to be a baseline in constituting any treaty to share water resources of Kabul River between Pakistan and Afghanistan.

\section{Acknowledgements}

It is a privilege to thankfully acknowledge the generous financial support being provided by the Higher Education Commission (HEC) of Pakistan through International Research Support Initiative Program (IRSIP) fellowship at the Department of Water Engineering and Management, University of Twente, The Netherlands. The author is grateful to Professor Dr. Arjen Y. Hoekstra, Chairman of Department of Water Engineering and Management, University of Twente, The Netherlands for giving the opportunity to work in his research group and providing his advice, inputs and valuable comments in finalizing this study.

\section{[References]}

[1] Bangash F K, Alam S. Quality parameters and its impact on the drinking water of Peshawar division Pakistan. J. Chem. Soc. Pak, 2003; 25: $125-132$

[2] Karn S K, Harada H. Surface water pollution in three urban territories of Nepal, India, and Bangladesh. Environ. Manage, 2001; 28(4): 483-496.

[3] Helen P J, Neal C, Paul J A. Sewage effluent phosphorus: A greater risk to river eutrophication than agricultural phosphorus. Science of the Total Environment, 2006; 360(1-3): 246-253.

[4] Liu C, Kroeze C, Hoekstra A Y, Gerbens Leenes W. Past and future trends in grey water footprints of anthropogenic nitrogen and phosphorus inputs to major world rivers. Ecol. Indic, 2012; 18: 42-49.

[5] Yan Y, Jia J, Zhou K, Wu G. Study of regional water footprint of industrial sectors: the case of Chaoyang city, Liaoning Province, China. Int. J. Sustain. Dev. World Ecol, 2013; 20 (6): 542-548.

[6] Manzardo A, Loss A, Fialkiewicz W, Rauch W, Scipioni A. Methodological proposal to assess the water footprint accounting of direct water use at an urban level: a case study of the municipality of Vicenza. Ecol. Indic, 2016: 69: 165-175.

[7] Eva M M, Deakin J, Archbold M, Gill L, Daly D, Bruen M. Sources of nitrogen and phosphorus emissions to Irish rivers and coastal waters: Estimates from a nutrient load apportionment framework. Science of The Total Environment, 2017; 601-602: 326-339,

[8] Serio F, Miglietta P P, Lamastra L, Ficocelli S, Intini F, De Leo F, et al. Groundwater nitrate contamination and agriculture land use: A grey water footprint perspective in South Apulia Region (Italy). Sciences of the Total Environment, 2018; 645: 1425-1431.

[9] Van Drecht G, Bouwman A F, Harrison J, Knoop J M. Global nitrogen and phosphate in urban wastewater for the period 1970 to 2050 . Global Biogeochem Cycles, 2009; 23(3): 1-19.

[10] Ogbonna D N. The impact of untreated sewage wastes discharge on the Physico-chemical properties of rivers in Port Harcourt metropolis. E-World Journal of Scientific Research and Reviews, 2014; 2(2): 1-19.

[11] Mekonnen M M, Hoekstra A Y. Global gray water footprint and water pollution levels related to anthropogenic nitrogen loads to fresh water. Environ. Sci. Technol, 2015; 49(21): 12860-12868.

[12] Mekonnen M M, Hoekstra A Y. Global anthropogenic phosphorus loads to freshwater and associated grey water footprints and water pollution levels: a high-resolution global study. Water Resour. Res, 2018; 54(1): 345-358

[13] Nafees M. Role of Kabul River in socio-economic activities and associated environmental problems. Central Asia Journal, 2012; 67: 1-6.

[14] Ejaz N, Hashmi H N, Ghumman A R. Water quality assessment of effluent receiving streams in Pakistan: a case study of Ravi River. Mehran University Research Journal of Engineering \& Technology, 2011; 30: 383-396.

[15] Khan B, Khan H, Muhammad S, Khan T. Heavy metals concentration trends in three fish species from Shah Alam River (Khyber Pakhtunkhwa Province, Pakistan). J. Nat. Environ. Sci, 2012; 3(1): 1-8.

[16] IUCN, Pollution and the Kabul River, An analysis and action planning, Department of Environmental Planning and Mangement, University of Peshawar, 1994. https://portals.iucn.org/library/node/8352
[17] Zakir S N, Ali L, Khattak S A. Variation in major element oxide with time in the soils of Peshawar Basin: their comparison with the normal agricultural soil. J. Himal. Earth Sci, 2013; 46(2): 35-48.

[18] Khan S, Shahnaz M, Jehan N, Rehman S, Shah M T, Din I. Drinking water quality and human health risk in Charsadda district Pakistan. J. Clean. Prod, 2013; 60: 93-101.

[19] Ahmad H, Yousafzai A M, Siraj M, Ahmad R, Ahmad I, Nadeem M S, et al. Pollution problem in River abul: Accumulation estimates of heavy metals in native fish pecies. Biomed Res. Int, 2015; 537368: 1-7. https://www.ncbi.nlm.nih.gov/pmc/articles/PMC4538320/

[20] World Bank. Scoping strategic options for development of the Kabul River basin, sustainable development department. South Asia Region, 2010. https://openknowledge.worldbank.org/handle/10986/18422

[21] Government of Afghanistan. Afghanistan national peace and development framework (ANPDF) 2017 to 2021. http://extwprlegs1.fao.org/docs/pdf/ afg148215.pdf

[22] Mustafa K. The News International: $5^{\text {th }}$ June, 2016 https://www.thenews.com.pk/print/125490-India-out-to-damage-Pakistanswater-interests-on-Kabul-river. Accessed on [2017-09-10]

[23] Shah M T, Tariq S. Environmental geochemistry of the soil of Peshawar Basin, NWFP, Pakistan, Journal of Chemical Society of Pakistan, 2007; 29(5): 438-445.

[24] Ahmad N, Noor S, Saleem M, Fazalullah. Water pollution studies of the urban and industrial areas of NWFP Pakistan, National Centre of Excellence in Physical Chemistry, University of Peshawar, 1982; 2: 25-34.

[25] Ahmad N, Khan F. Dissolved oxygen and biochemical oxygen demand of Kabul River and industrial wastewaters of Nowshera industrial area. National Centre of Excellence in Physical Chemistry, University of Peshawar, 1983; 3: 87-95.

[26] Kamin K, Arif M, Khattak M A, Shah R A. Chemical characteristic of drinking water of NWFP Part-1, Pakistan Council Scientific and Industrial Reseach (PCSIR) Peshawar, Pakistan, 1985.

[27] Sohail A. Bottom fauna and organic matter in bottom mud of kabul-indus drainge system. Master thesis, Department of Zoology, University of Peshawar, Pakistan, 1989.

[28] Nafees M, Ghulam K. Environmental impact assessment of amangarh industrial estate, Nowshera. Mphil thesis, Department of environmental planning and management, University of Peshawar Pakistan, 1992.

[29] Nawab B. Evaluation of sewage water pollution in peshawar city, Master thesis, Department of environmental planning and management, University of Peshawar, Pakistan; 1992.

[30] Khattak R A, Rehman A. Effect of disposal on industrial waste on the quality of Kabul River water and soil at Pirsabaq. Master thesis, University of Agriculture Peshawar, Pakistan, 1992.

[31] Wahid A, Muhammad G. Impact of industrial effluents on wheat and aquatic fauna (fishes) in River Kabul near Amangarh. Mater thesis, Department of environmental planning and management, University of Peshawar Pakistan, 1992.

[32] Pervez S. The flood plain vegetation of Kabul River and its tributaries in duaba-daudzai area near Peshawar. Master thesis, area study center, University of Peshawar Pakistan; 1993.

[33] Iqrar M. Survey of Khazana sugar mill, Peshawar a case study of nasir killy village program. Master thesis, Department of environmental planning and management, University of Peshawar Pakistan; 1994.

[34] Khan T, Muhammad S, Khan B. Investigating the levels of selected heavy metals in surface water of Shah Alam River (A tributary of River Kabul, Khyber Pakhtunkhwa). Journal of Himalayan Earth Sciences, 2011; 44(2): 71-79.

[35] Akif M, Khan A R, Sok K, Hussain Z. Textile effluents and their contribution towards aquatic pollution in the Kabul River (Pakistan). Jour. Chem. Soc. Pak, 2002; 24(2): 106-111.

[36] Khan S A, Khan M. Water quality characteristics of the Kabul River in Pakistan under high flow conditions. Jour. Chem. Soc. Pak, 1997; 19(3): 201-209.

[37] Khan A R, Akif M, Wadud S, Khan K. Pollution studies of kabul river and its tributaries for the assessment of organic strength and fecal coliform. Jour. Chem. Soc. Pak, 1999; 21(1): 41-47.

[38] Khan A R, Kashif M, Riaz M. Impact of industrial discharge on the quality of Kabul River water at Amangarh, Nowshera, Pakistan. Jour. Chem. Soc. Pak, 1999; 21(2): 97-105.

[39] Yousafzai A M, Khan A R, Shakoori A R. An assessment of chemical pollution in River Kabul and its possible impacts on fisheries. Pak. J. Zool, 2008; 40(3): 199-210. 
[40] Iqbal U, Qasim H, Khan A K, Rashid R, Nasreen S, Mahmood Q, et al. Surface and ground water quality risk assessment in district Attock Pakistan. World Appl. Sci. J, 2009; 7(8): 1029-1036.

[41] Yousafzai A M, Khan A R, Shakoori A R. Pollution of large, subtropical rivers-river kabul, Khyber Pakhtunkhwa Povince, Pakistan: Physico-chemical indicators. Pak. J. Zool, 2010; 42(6): 795-808.

[42] Nosheen G, Ullah M, Khan K A, Rehman A. Impacts of industrial effluent on River Kabul, Hydro Nepal. Journal of Water, Energy and Environment, 2011; 8: 44-47.

[43] Ullah Z, Khan H, Waseem A, Mahmood Q, Farooq U. Water quality assessment of the river kabul at peshawar, pakistan: industrial and urban wastewater impacts. J. Water Chem. Technol, 2013; 35(4): 170-176.

[44] Jan A N, Khan Q, Khan A, Raziq S, Muhammad A. Monitoring of water quality parameters to know the suitability of water for fish fauna at river Sardaryab, Khyber Pakhtunkhwa, Pakistan. The Journal of Zoology Studies, 2014; 1(3): 31-37.

[45] Rauf M, Ullah S, Haseeb A, Shah H, Khan M. Physiochemical Investigation of River Kabul at Michini, Khyber Pakhtunkhwa, Pakistan. Journal of biodiversity and environmental sciences, 2015; 7(3): 280-291.

[46] Akhtar S M, Iqbal J. Assessment of emerging hydrological, water quality issues and policy discussion on water sharing of transboundary Kabul River. Water Policy, 2017; 19(4): 650-672.

[47] Ma D, Xian C, Zhang J, Zhang R, Ouyang Z. The Evaluation of water footprints and sustainable water utilization in Beijing. Sustain, 2015; 7(10): 13206-13221.

[48] Fang K, Heijungs R, Duan Z, De Snoo G R. The environmental sustainability of nations: benchmarking the carbon, water and land footprints against allocated planetary boundaries. Sustain, 2015; 7(8): 11285-11305.

[49] Chen $\mathrm{H} \mathrm{S}$. Using water footprints for examining the sustainable development of science parks. Sustain, 2015; 7(5): 5521-5541.

[50] Pellicer-Martnez F, Martnez-Paz J M. The water footprint as an indicator of environmental sustainability in water use at the river basin level. Sci. Total Environ, 2016; 571: 561-574.

[51] Miglietta P P, Toma P, Fanizzi F P, De Donno A, Coluccia B, Migoni D, et al. A grey water footprint assessment of groundwater chemical pollution: Case study in salento (Southern Italy). Sustain, 2017; 9(5). https://doi.org/10.3390/su9050799

[52] Government of Pakistan, Bureau of Statistics, 2017. http://www.pbs.gov.pk/, Accessed on [2017-11-09].

[53] Favre R, Kamal G M. Watershed atlas of Afghanistan, Ministry of Irrigation, Water Resource and Environment, Kabul, Afghanistan, 2004. http://dwms.fao.org/ draft/prod_watersheds_en.asp

[54] Government of Pakistan, National Fertalizer Development Centrre, National Fertalizer Annual Report, Islamabad, 1986-2015. http://www.pbs.gov.pk/

[55] Government of Pakistan, Agriculture Census Organization. Census of livestock, NWFP Report, Lahore 1986-2015. http://www.pbs.gov.pk/

[56] FAO, Livestock Sector Brief, Pakistan, Livestock Information Sector, Analysis and Policy Branch, 2003. http://www.fao.org/ag/againfo/ resources/en/publications/sector_briefs/lsb_PAK.pdf

[57] Yousif O K, Babiker S A. The desert camel as a meat animal. Meat Sci. 1989; 26 (4): 245-254.

[58] Sheldrick W, Keith Syers J, Lingard J. Contribution of livestock excreta to nutrient balances. Nutr. Cycl. Agroecosystems, 2003; 66 (2): 119-131.

[59] Bouwman A F, Lee D S, Asman W A H, Dentener F J, Van Der Hoek K W, Olivier J G. Global high resolution emission inventory for ammonia. Global Biogeochemical Cycles, 1997; 561-587. https://doi.org/10.1029/ 97GB02266

[60] FAO. FAOSTAT online database; Food and Agriculture Organization, 2012. http://www.fao.org/faostat/en/

[61] Morée A L, Beusen A H W, Bouwman A F, Willems W J. Exploring global nitrogen and phosphorus flows in urban wastes during the twentieth century. Glob. Biogeochem. Cycle, 2013; 27(3): 836-846. https://doi.org/10.1002/gbc.20072

[62] Food and Agriculture Organization (FAO), World Health Organization (WHO), and UNU. Energy and protein requirements, 1985; 724: Geneva. http://www.fao.org/3/a-y5686e.pdf

[63] Calloway D H, Odell A C F, Margen S. Sweat and miscellaneous nitrogen losses in human balance studies. Journal of Nutrition, 1971; 101(6): 775-786.

[64] Kimura S D, Liang L, Hatano R. Influence of long-term changes in nitrogen flows on the environment: a case study of a city in Hokkaido, Japan. Nutr. Cycling Agroecosyst, 2004; 70 (3): 271-282.

[65] Qureshi Z, Water and sanitation in Khyber Pakhtunkhwa. South Asian cities confrence Karachi, Pakistan Urban Forum, January $10^{\text {th }}-12^{\text {th }} 2014$.

[66] Government of Pakistan, Water and Power Developent Authority (WAPDA), Tarbella, Pakistan, 1986-2015.

[67] Hoekstra A Y, Chapagain A K, Aldaya M M, Mekonnen M M. The Water Footprint Assessment Manual, 2011. https://waterfootprint.org/ media/downloads/TheWaterFootprintAssessmentManual_2.pdf

[68] Franke N A, Boyacioglu H, Hoekstra A Y. Grey water footprint accounting, Tier 1 supporting guidelines, UNESCO-IHE, Institute of Water Education, Delft, Netherlands, 2013. https://waterfootprint.org/ media/downloads/Report65-GreyWaterFootprint-Guidelines_1.pdf

[69] Nafees M, Ahmad F, Butt M N, Khurshed M. Effects of water shortage in Kabul River network on the plain areas of Khyber Pakhtunkhwa, Pakistan. Environ. Monit. Assess. 2018, 190(6). https://link.springer.com/ article/10.1007/s10661-018-6730-3

[70] Correll D L. The role of phosphorus in the eutrophication of receiving waters: A review. J. Environ. Qual, 1998; 27: 261-266.

[71] Almadullah R, Dongshik K. Assessment of potential dam sites in the Kabul river basin using GIS. Inter. J. Adv. Comp. Sci. Appl, 2015; 6(2): 83-89. 